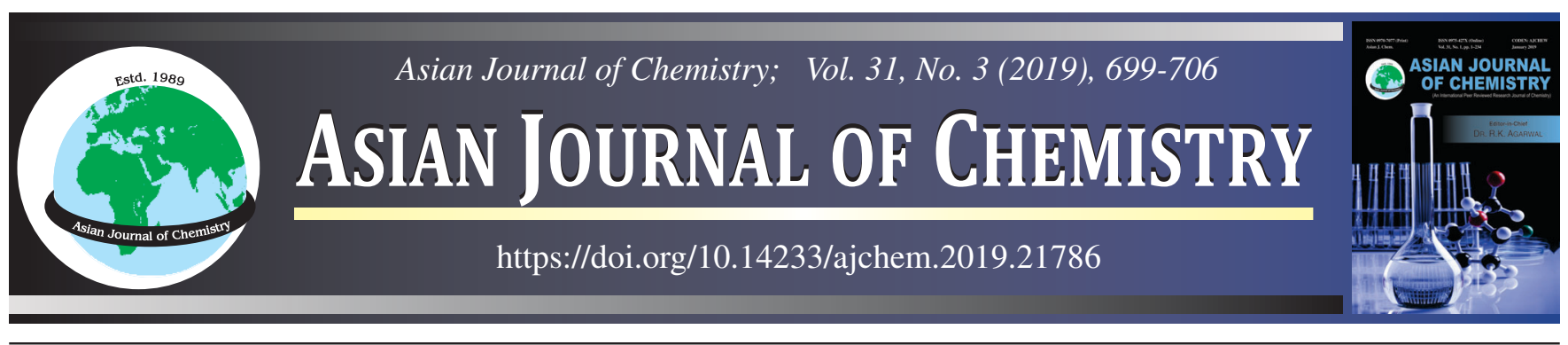

\title{
Sediments and Water Column Contamination by Heavy Metals in Ekulu River, Nigeria: Ecological and Human Health Risk Assessment
}

\author{
Uzochukwu Cornelius Ugochukwu*, Onyechi Henry Onuora, Chizoba Agu,
} Kurumeh Leonard, John C. Ewoh, Iyke Ezeasor and Amaka Lynda Onuorah

Shell/UNN Centre for Environmental Management \& Control, University of Nigeria, Enugu Campus, Nigeria

*Corresponding author: E-mail: uzochukwu.ugochukwu@unn.edu.ng

Received: 30 October 2018; Accepted: 12 December 2018; Published online: 31 January 2019;

Acid mine drainage from a defunct coal mine, agricultural run-off and indiscriminate waste disposal constitute major threat to the quality of Ekulu river of Enugu State, Nigeria. In this study, Ekulu river sediments and water column pollution by heavy metals and the associated ecological and human health exposure risks were assessed. The heavy metals were measured using atomic absorption spectrometry. The parameters used in assessing the pollution of the sediments were contamination factor, contamination degree, geochemical accumulation index and pollution load index whereas the ecological risk of the heavy metals in the sediments was assessed using potential ecological | risk index. The parameters employed in assessing the carcinogenic and non-carcinogenic risks of exposure by humans to the heavy metals | were hazard index and risk index. The results obtained indicate that the chromium and lead input into the sediments around the defunct coal mine area during the wet season was significant and most probably due to the discharge of acid coal mine drainage into the river. Elevated values of ecological and human health exposure risks around $4 \mathrm{~km}$ distance away (Damija) from the defunct coal-mine area are most likely due to anthropogenic activities.

Keywords: Ecological risks, Heavy metals, Human health, Risk assessment, River, Sediment.

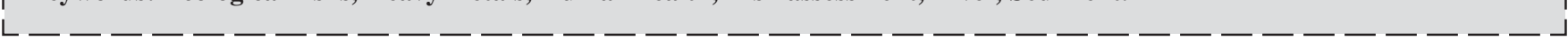

\section{INTRODUCTION}

The need for the protection of aquatic ecosystem is extremely important not only for the benefit of the aquatic biota but also for the health of humans who use the given water resources. More so when water bodies can easily transport pollutants from point of entry to several kilometers down field putting several organisms at risk.

Natural processes such as the weathering of minerals have the potential to release heavy metals into the aquatic environment. However, release of heavy metals into the environment from natural processes is considered low/insignificant compared with anthropogenic releases. Anthropogenic sources are usually the main sources of environmental pollution by heavy metals as could be found in water columns and sediments of rivers that receive effluent and wastes from nearby sources of pollution [1-3]. Anthropogenic activities manifesting in form of steady growth in industrialization and urbanization in many countries of the world is highly associated with increase in the release of some environmental pollutants such as heavy metals [4]. The discharge of wastewater from industrial effluent of manufacturing/processing companies, coal mine acid drainage, application of inorganic fertilizer, sludge from sewage and deposition of atmospheric pollutants have been reported to constitute the principal contributors of heavy metals found in sediments and water columns of rivers $[2,5,6]$.

Heavy metals are deleterious to the environment and public health as a result of their toxicity not just to humans but also to biota whether terrestrial or aquatic $[7,8]$. Furthermore, the non-biodegradability of heavy metals makes them persist in the environment and as a result bioaccumulate in vertebrates especially in the bones and brains [8]. Through trophic transfers, there could be biomagnifications of heavy metals in higher trophic levels of the food web with dire health consequenses. Heavy metals could enter water bodies such as rivers via direct effluent discharge to the rivers and could be a massive problem especially in developing countries where effluent quality standard is not strictly enforced by regulatory

This is an open access journal, and articles are distributed under the terms of the Creative Commons Attribution-NonCommercial-ShareAlike 4.0 (CC BY-NC-SA 4.0) International License which allows readers to freely read, download, copy, distribute, print, search, or link to the full texts of its articles and to use them for any other lawful non-commercial purpose as long as the original source is duly acknowledged. 
authorities. Another means of entry into rivers could be by run-off carrying the heavy metals from already polluted soil and transporting the heavy metals (which are partitioned in the water phase and sediments) to the river and polluting the later [9].

Bentic organisms depend on bottom sediments for food and habitats hence pollution of bottom sediments will directly affect these organisms [10]. Sediments act as reservoirs to the heavy metals and under certain conditions of perturbations, the heavy metals could be released into the water column increasing risk of ecological harm to organisms inhabiting the water column $[11,12]$. This means that the pollution of sediments not only pose risks to the biota inhabiting the sediments but also pose risks to those organisms inhabiting the river column such as fishes as well. Consequent upon the bioaccumulation of heavy metals in the aquatic biota and subsequent biomagnifications in higher trophic organisms that inhabit terrestrial ecosystems, terrestrial organisms can be analyzed to understand the extension of the effects of pollution by heavy metals that started from the aquatic environment [13].

The extent of heavy metal contamination of the sediments of rivers can be evaluated employing several methods such as enrichment factor, index of geo-accumulation, metal contamination factor and the associated contamination degree and pollution index load $[2,3,14,15]$. Reviewed literature shows that the ecological risk assessment of the sediments due to heavy metal pollution can be evaluated via estimation of biological impairment using sediment quality guidelines (SQGs) [16]. Also, the risk assessment can be carried out by evaluating the ecological risk of the heavy metals in the sediments via potential ecological risk index (PERI) as proposed by Hakanson [17]. Several literatures have reported the application of these methods in assessing the ecological risks of heavy metals in sediments [18-20].

Ekulu river which is the focus of this study, is a $25 \mathrm{~km}$ long river that drains through Enugu metropolis of Enugu State, Nigeria. The population of Enugu metropolis as per 2006 census is over 700,000. There are several anthropogenic activities in the metropolis that are expected to have impact on Ekulu river, namely, the defunct coal mining activities, agricultural practices and use of fertilizer especially inorganic fertilizer, indiscriminate waste dumping etc. Several studies have been reported on the water quality of Ekulu river and other rivers draining through Enugu metropolis [21-24]. However, these studies reported findings only on the water quality of Ekulu river and other rivers draining the metropolis. Studies on the sediment quality and ecological risks of the heavy metals in Ekulu river sediment are not reported yet. Also, studies on risks of human health exposure to heavy metals in Ekulu river is not well reported. Studies of this kind are very important for policy formulation and implementation required for the protection of aquatic ecosystem and public health with respect to Ekulu river. This study is therefore carried out to achieve the following objectives:

(a) Determine the concentration of heavy metals in the water column and sediment of Ekulu river within a $5 \mathrm{~km}$ distance from Onyeama (defunct coal mine area).

(b) Determine the degree of pollution of the water column and sediments by heavy metals. (c) Assess the human health and ecological risks of the heavy metals in the river.

\section{EXPERIMENTAL}

Study area: The study area, shown in Fig. 1 is Enugu metropolis, the administrative headquarters of Enugu State, Nigeria. It is located geographically between latitude $6^{\circ} 21^{\prime} \mathrm{N}$ and $6^{\circ} 30^{\prime} \mathrm{N}$ and between longitude $7^{\circ} 25^{\prime} \mathrm{E}$ and $7^{\circ} 37^{\prime} \mathrm{E}$. The main land use of the study area is agricultural, industrial, commercial and residential. The area has been transformed to derived savannah with temperature ranging between 25 and $35^{\circ} \mathrm{C}$ and annual rainfall of about $950 \mathrm{~mm}$. The geology of the area comprises Enugu shale, which is overlain by mamu formation that is in-turn overlain by Ajali formation in quick succession [25]. Rainy season (April-October) and dry season (November-March) are the two seasons of the study area. This study is centered on Ekulu river which is a fast flowing perennial river that drains through the metropolis and receives waste discharges from several anthropogenic activities. The defunct Onyeama coal mine in the study area is a major influence on the sediment and water quality of Ekulu river. Onyeama coal mine is in Enugu Coal Field and was abandoned just like other coal mines in Enugu some decades ago due to a shift of emphasis from coal to oil and gas arising from the discovery of oil and gas in the Niger delta region of Nigeria. Coal mine water from Onyeama mine especially during the rainy season when the mine is flooded, discharges into Ekulu river used by nearby residents to the river for washing clothing and cars, bathing, swimming and cooking. In this study, the Onyeama area constituted a sampling point whereas $4 \mathrm{~km}$ downstream Onyeama mine was another sampling point identified as 'Damija'. The third sampling point which is about $1 \mathrm{~km}$ downstream Damija is identified as 'The Hotel'. The study area and sampling locations are as presented in Fig. 1.

Sampling: Samples for this study were collected in triplicates fortnightly in October, 2017 and February, 2018 to cover both the wet and dry seasons. Sampling locations are as shown in Fig. 1. The sampling locations were selected to include the waterfall zone, Damija zone and The Gate hotel zone. Damija zone is located $2.5 \mathrm{~km}$ downstream the waterfall zone and $1.5 \mathrm{~km}$ upstream The Gate hotel zone. Surficial sediment samples were collected at a depth of 0-10 cm using stainless steel corer at three points (river bed periphery-2 samples and mid river bed-1 sample) from each of the sampling locations. The sediment samples were collected into a polythene bag and sealed.

The water samples were collected at the river-water column that corresponds to the points sediment samples were collected. The water samples were collected into a $1 \mathrm{~L} \mathrm{HNO}_{3}$ pre-washed polyethylene containers. Preservation of the heavy metals in the water samples was achieved by acidifying the samples using $5 \mathrm{~mL}$ of $6 \mathrm{M} \mathrm{HNO}_{3}$ prior to transportation to the laboratory for analysis. The sediment and water samples were put into a sampling box filled with ice cubes for maintaining sample temperature below $4{ }^{\circ} \mathrm{C}$ and transported to the laboratory for analysis.

\section{Laboratory analysis}

Analysis of sediment samples: The sediment samples were air dried and passed through a $2 \mathrm{~mm}$ mesh sieve to remove 


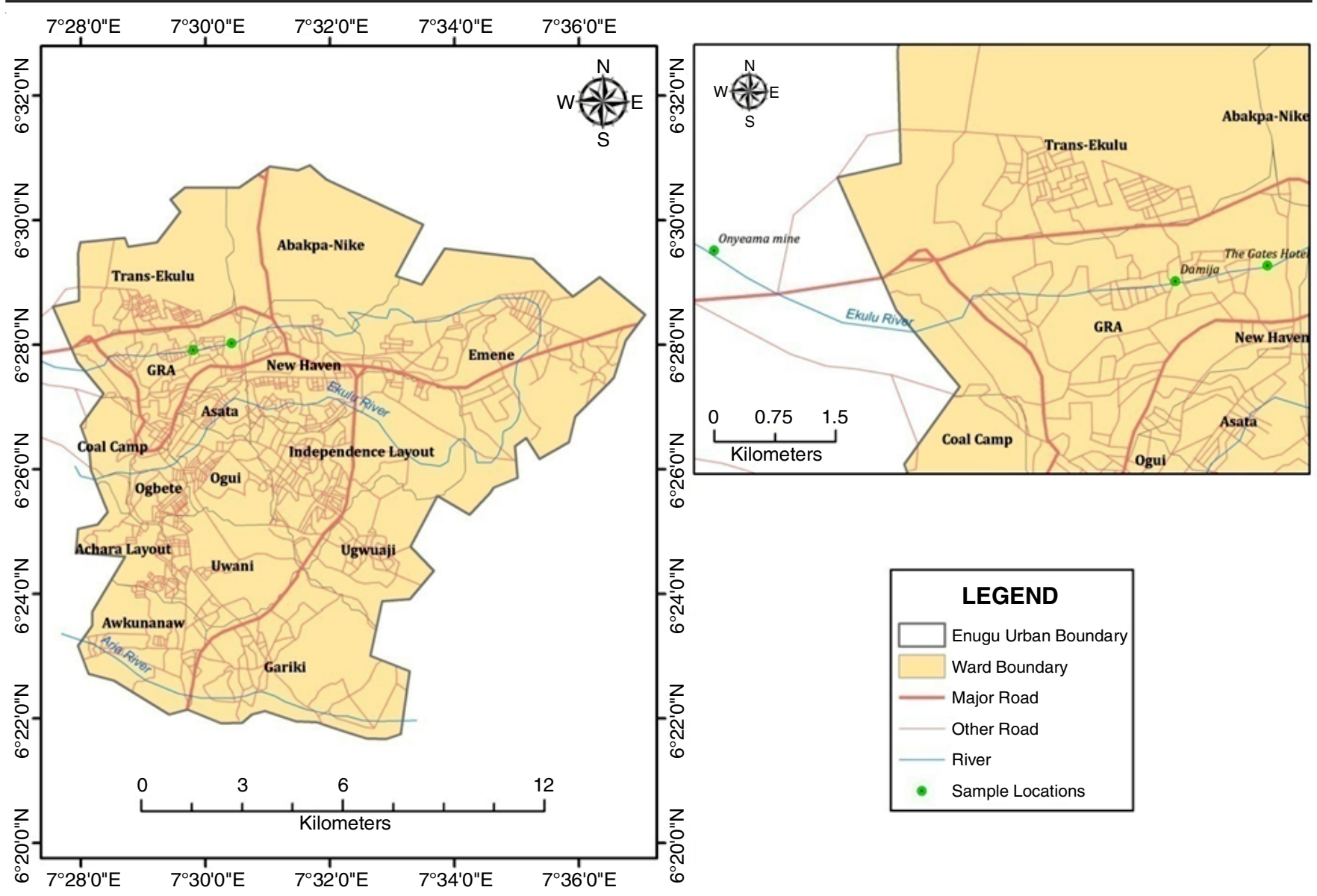

Fig. 1. Map of the study area showing sampling locations, Onyeama mine (waterfall) covering a distance of about $5 \mathrm{~km}$

plant debris and stones. The sieved sediment samples were ground to powder using pestle and mortar and passed through a $3 \mathrm{~mm}$ mesh sieve to collect fine sediment samples. The US EPA method [26] was adopted in acid digestion of the sediment samples. This method involves using $65 \% \mathrm{HNO}_{3} / 35 \% \mathrm{HCl}$ at a ratio of 3:1 v/v to digest the sediment samples in a Teflon vessel in a microwave oven at the appropriate sediment/acid mix ratio. In this study, $12 \mathrm{~mL}$ of acid mix was used in digesting $0.25 \mathrm{~g}$ of sediment sample. After microwave digestion, deionized water was added and the solution filtered using 0.45 $\mu \mathrm{m}$ filter membrane. Additional water was added to make up the volume to $50 \mathrm{~mL}$ and stored in the refrigerator below $4{ }^{\circ} \mathrm{C}$ until required for analysis. The heavy metals $(\mathrm{Cu}, \mathrm{Zn}, \mathrm{Cr}$, $\mathrm{Pb}, \mathrm{Cd}$ ) were analyzed using SensAA GBC flame atomic absorption.

Analysis of water samples: Aliquots of $100 \mathrm{~mL}$ taken from the collected water samples were filtered using Whatman filter paper. The filtrate was collected and analyzed for heavy metals using the SensAA GBC flame atomic absorption.

Quality control: Duplicate sample and blank analysis were carried out in order to confirm the method accuracy. Limit of detection (LOD), limit of quantification (LOQ) and recoveries were also determined. The LOD was determined as three times the standard deviation of 10 replicate blank measurements [27]. The LOQ was determined as three times the LOD value. The $\mathrm{LOD}$ varied from $0.2-0.5 \mu \mathrm{g} / \mathrm{L} ; \mathrm{LOQ}$ varied from $0.0005-0.0015 \mu \mathrm{g} / \mathrm{L}$; recoveries varied from $81-104 \%$. All the laboratory analysis were carried out in triplicates and the relative standard deviation for all samples varied between 7.3 and $14.7 \%$.

Pollution assessment and ecological risks due to heavy metals in the sediments: Ecological assessment of the sediments polluted by heavy metals was carried out by means of contamination factor (CF), degree of contamination (DC), geo-accumulation index $\left(\mathrm{I}_{\text {geo }}\right)$, pollution load index (PLI) and potential ecological risk index (PERI).

Contamination factor: Contamination factor $(\mathrm{CF})$ was determined as proposed by Hakanson [17]:

$$
\mathrm{CF}=\frac{\mathrm{C}_{\text {sediment }}}{\mathrm{C}_{\text {background }}}
$$

where: $\mathrm{C}_{\text {sediment }}=$ heavy metal mean concentration in the sediment; $\mathrm{C}_{\text {background }}=$ heavy metal concentration in the background.

The background values used were those reported by Hakanson [17].

Degree of contamination (DC): The degree of contamination is estimated by adding the contamination factor (CF) for all the heavy metals in the sample as described in eqn. 4.

$$
\mathrm{DC}=\mathrm{CF}_{1}+\mathrm{CF}_{2}+\mathrm{CF}_{3}+\ldots \ldots \ldots \ldots \ldots \mathrm{CF}_{\mathrm{n}}
$$

Geo-accumulation index $\left(\mathbf{I}_{\mathbf{g e o}}\right)$ : The geo-accumulation index $\left(\mathrm{I}_{\mathrm{geo}}\right)$ is determined as follows:

$$
\mathrm{I}_{\mathrm{geo}}=\log _{2}\left(\frac{\mathrm{C}_{\mathrm{n}}}{1.5 \mathrm{~B}_{\mathrm{n}}}\right)
$$


where: $C_{n}=$ concentration of heavy metals in the sediment; $B_{n}$ = geochemical background value; 1.5 is matrix correction factor that minimizes lithogenic effects [10].

Pollution load index (PLI): Pollution load index measures the extent of pollution of the sediments and is expressed as proposed by Tomlinson et al. [28]:

$$
\mathrm{PLI}=\left(\mathrm{CF}_{1} \times \mathrm{CF}_{2} \times \mathrm{CF}_{3} \times \ldots \ldots \ldots \ldots . . . \mathrm{CF}_{\mathrm{n}}\right)^{1 / \mathrm{n}}
$$

where: $\mathrm{CF}=$ contamination factor; $\mathrm{n}=$ number of heavy metals in the sediment sample.

Potential ecological risk index (PERI): Potential ecological risk index of the heavy metals in the sediments, which is derived from summing the potential ecological risk factor (PERF) of the individual heavy metals is given as described in eqn. 7.

$$
\mathrm{PERF}=\mathrm{CF} \times \mathrm{TRC}
$$

where: $\mathrm{CF}=$ contamination factor; $\mathrm{TRC}=$ toxic response coefficient for a given heavy metal. This study adopted the TRC reported in Hakanson [17]. TRC is a measure of the toxicity and ecological sensitivity of the heavy metals.

$$
\mathrm{PERI}=\mathrm{PERF}_{1}+\mathrm{PARF}_{2}+\mathrm{PERF}_{3}+\ldots \ldots \ldots \ldots \mathrm{PERF}_{\mathrm{n}}
$$

Human health risk exposure to heavy metals in the water column and sediments: Ekulu river is used for cooking, bathing/swimming and washing hence the possible exposure to health risks due to heavy metals in both the water column and sediments.

Non-carcinogenic risks of exposure to heavy metals in the water column: The hazard quotient (HQ) and hazard index (HI) are determined as follows:

$$
\mathrm{HQ}=\mathrm{D} / \mathrm{RfD}
$$

where: $\mathrm{D}=$ exposure dose of the heavy metal; $\mathrm{RfD}=$ reference dose.

$$
\mathrm{HI}=\Sigma \mathrm{HQ} \text { (for all the heavy metals detected) }
$$

The detailed equations for determining chronic exposure dose in this study, definition of terms and parameter values are as reported in Ugochukwu and Ochonogor [29]. For this study, exposure duration of 35 years was used.

The dermal permeability coefficient and reference dose of the heavy metals used in this study are as presented in Table-1.

Non-carcinogenic risks of exposure to heavy metals in sediments: Hazard quotient (HQ) and hazard index (HI) were used in estimating the non-carcinogenic risks of exposure to heavy metals in the sediments according to eqns. 9 and 10. The equations and parameter values for computing the chronic exposure dose of the sediments are as reported in Ugochukwu et al. [34]. Exposure term is assumed to be $3 \mathrm{~h}$ a day, 7 days a week, 52 weeks a year, exposure period of 35 years [35].
TABLE-1

DERMAL PERMEABILITY COEFFICIENT AND

REFERENCE DOSE OF THE HEAVY METALS AS ADAPTED FROM [Ref. 30-33]

\begin{tabular}{cccc}
\hline Heavy & $\begin{array}{c}\text { Dermal permeability } \\
\text { metal }\end{array}$ & \multicolumn{2}{c}{ Reference dose $(\mathrm{RfD})(\mathrm{mg} / \mathrm{Kg}-\mathrm{d})$} \\
\cline { 3 - 4 } $\mathrm{Pb}$ & 0.0040 & $\mathrm{RfDi}$ & $\mathrm{RfDd}$ \\
$\mathrm{Cu}$ & 0.0010 & 0.0035 & 0.000520 \\
$\mathrm{Cr}$ & 0.0020 & 0.0400 & 0.012000 \\
$\mathrm{Zn}$ & 0.0006 & 0.0030 & 0.000060 \\
$\mathrm{Cd}$ & 0.0010 & 0.3000 & 0.060000 \\
\hline
\end{tabular}

$\mathrm{RfDi}=$ Reference dose due to ingestion; $\mathrm{RfDd}=$ Reference dose due to dermal absorption

$$
\mathrm{ET}=(3 / 24 \times 7 / 7 \times 52 / 52 \times 35 / 35)=0.125
$$

Carcinogenic risks of exposure to heavy metals as a result of ingestion of the river water: Carcinogenic risks were estimated using excess life cancer risks (ELCR) and risk index (RI) as follows:

$$
\mathrm{ELCR}=\mathrm{D} \times \mathrm{SF}
$$

where: $\mathrm{D}=$ exposure dose (mg/kg-day); $\mathrm{SF}=$ slope factor $(\mathrm{mg} /$ kg-day) $)^{-1}$.

$$
\mathrm{RI}=\Sigma \mathrm{ELCR} \text { (for chromium, lead and cadmium) }
$$

\section{RESULTS AND DISCUSSION}

Concentration of the heavy metals in sediment and water column: The concentration of the heavy metals in the sediments and water column of Ekulu river as measured (within the period of October, 2017 and February, 2018) from samples collected within the Waterfall (Onyeama mine) zone, Damija zone and The Hotel zone is as presented in Table-2.

During the rainy season, the concentration of $\mathrm{Pb}$ and $\mathrm{Cr}$ in the sediments of Ekulu river at the location of Waterfall (around Onyeama mine) is significantly higher than in Damija and The Gate Hotel probably due to the high concentration of these two heavy metals in acid mine drainage that get discharged into Ekulu river from closed mines [23]. However, as a result of so many anthropogenic activities that exist around Damija area, there appears to be cadmium pollution in the sediments of the river within this area as the concentration of cadmium is significantly higher than in Waterfall and The Gate Hotel (Table-2). During the dry season, there is no significant difference in the concentration level of $\mathrm{Pb}$ among the three locations but $\mathrm{Cr}$ and $\mathrm{Zn}$ concentration levels are significantly

\begin{tabular}{|c|c|c|c|c|c|c|c|c|}
\hline \multirow{2}{*}{$\begin{array}{l}\text { Heavy } \\
\text { metals }\end{array}$} & \multicolumn{4}{|c|}{ Concentration values $(\mathrm{mg} / \mathrm{Kg})$ for October, 2017} & \multicolumn{4}{|c|}{ Concentration values $(\mathrm{mg} / \mathrm{Kg}$ ) for February 2018} \\
\hline & Onyeama & Damija & $\begin{array}{c}\text { The Gate } \\
\text { Hotel }\end{array}$ & $\begin{array}{l}\text { River sediment } \\
\text { average }\end{array}$ & Onyeama & Damija & $\begin{array}{c}\text { The Gate } \\
\text { Hotel }\end{array}$ & $\begin{array}{l}\text { River sediment } \\
\text { average }\end{array}$ \\
\hline $\mathrm{Pb}$ & 121 & 0.02 & 33.7 & 51.6 & 53.8 & 45.2 & 36.4 & 45.1 \\
\hline $\mathrm{Cu}$ & 6.7 & 7.7 & 4.6 & 6.3 & 9.5 & 23.3 & 16.4 & 16.4 \\
\hline $\mathrm{Cr}$ & 127.1 & 43.4 & 45.3 & 71.9 & 40.8 & 75.2 & 88.4 & 68.1 \\
\hline $\mathrm{Zn}$ & 17.1 & 0.6 & 87.1 & 34.9 & 19.1 & 77.3 & 141.5 & 79.3 \\
\hline $\mathrm{Cd}$ & 3 & 12.2 & 2.2 & 5.8 & 4.5 & 8.6 & 2.8 & 5.3 \\
\hline
\end{tabular}
higher in Damija and the The Gate Hotel than Waterfall indicating possible input from anthropogenic activities (Table-2). Still in the dry season, there is no significant difference between the cadmium concentration level in The Gate Hotel and Water-

TABLE-2

CONCENTRATION OF THE HEAVY METALS IN THE VARIOUS SAMPLING LOCATIONS OF THE EKULU RIVER SEDIMENTS AS SAMPLED IN OCTOBER, 2017 AND FEBRUARY, 2018. VALUES ARE PRESENTED AS MEAN 
fall but there is significant difference between the concentration level of cadmium in Damija and ether of the other two locations further lending credence to the input of cadmium from anthropogenic activities within the Damija area.

The average concentrations of the heavy metals in the sediments of Ekulu river in comparison with those of the rivers from other regions of the world are as presented in Table-3.

The average concentration level of $\mathrm{Pb}$ in the sediments of Ekulu river is higher than the level reported for other rivers in Nigeria such as river Benue. Furthermore, in comparison with the rivers of other regions of the world such as Yellow river, China, Lake Awassa Ethiopia, the concentration level of $\mathrm{Pb}$ in Ekulu river is higher (Table-3). However, the reported concentration level of $\mathrm{Pb}$ in the sediments of Bangshi river, Bangladesh; Lijiang river, China; Neretva river Valley, Croatia; Almendares river, Cuba; Axos river, Greece and Gomti river, India is higher than that of Ekulu river, Nigeria (Table-3). For Cr, the concentration levels in sediments of Lake Awassa of Ethiopia and Neretva river Valley of Croatia are lower than the level in the sediments of Ekulu river while the other rivers mentioned above have higher values (Table-3). The average concentration levels of $\mathrm{Cu}$ and $\mathrm{Zn}$ in the sediments of Ekulu river are the lowest in comparison with the levels in all the other rivers mentioned above. Axos river, Greece and Gomti river, India are examples of rivers with higher $\mathrm{Cd}$ concentration levels in their sediments than that of Ekulu river (Table-3).

The average $\mathrm{Pb}, \mathrm{Cr}, \mathrm{Cu}, \mathrm{Zn}$ and $\mathrm{Cd}$ concentration levels in Ekulu river sediment are lower than the Canadian Council of Ministers of the Environment (CCME) probable effect level (PEL) of 91.3, 90, 197, 315 and $15.5 \mathrm{mg} / \mathrm{kg}$ [51] indicating insignificant or low ecological risk. However, within the Waterfall area where during the rainy season, acid mine drainage gets discharged into the river, the concentration levels of $\mathrm{Pb}$ and $\mathrm{Cr}$ of 121 and $127.1 \mathrm{mg} / \mathrm{kg}$ (Table-4) exceed the CCME PEL indicating probable significant ecological impairment.

The concentration of the heavy metals in the river column is as presented in Table-4. The water column of Ekulu river is contaminated with $\mathrm{Pb}$ at all the locations for all seasons as the $\mathrm{Pb}$ concentration level exceeds that of World Health Organization (WHO) maximum allowable contaminant level (MACL) of $0.01 \mathrm{mg} / \mathrm{L}$. During the rainy season, the concentration of $\mathrm{Cr}$ in the water column of Ekulu river in Damija and The Gate Hotel areas exceed the WHO MACL of $0.05 \mathrm{mg} / \mathrm{L}$. During the rainy season, only the Gate Hotel is contaminated with $\mathrm{Cd}$ with concentration level of $0.01 \mathrm{mg} / \mathrm{L}$ which is higher than $0.003 \mathrm{mg} / \mathrm{L}$ that is the WHO MACL for Cd (Table-4). The concentration of copper for all the seasons is quite lower than the WHO MACL of $2 \mathrm{mg} / \mathrm{L}$.

The average concentrations of the heavy metals in the river water column of samples collected at The Gate Hotel, Damija and Waterfalls for the wet and dry season of this study in comparison with those of the rivers from other regions of the world are as presented in Table-5.

In comparison with other rivers in Nigeria such as river Argungu, $\mathrm{Pb}, \mathrm{Cu}, \mathrm{Zn}$ and $\mathrm{Cd}$ concentration levels in Ekulu river are lower but $\mathrm{Cr}$ concentration level is higher in Ekulu river. The reported concentration levels of all the studied heavy metals in the water column of the rivers of other parts of the world such as Tembi river, Iran and Odiel river, Spain are higher than those of Ekulu river.

Pollution and ecological risk indices: The pollution indices utilized in evaluating the extent of pollution in this study are contamination factor (CF) and degree (CD), geochemical accumulation index $\left(\mathrm{I}_{\mathrm{geo}}\right)$ and pollution load index (PLI) whereas

TABLE-3

CONCENTRATION OF THE HEAVY METALS IN SEDIMENTS OF EKULU RIVER (SEDIMENT AVERAGE FOR WET AND DRY SEASON) AS COMPARED WITH THE RIVERS OF OTHER REGIONS OF THE WORLD

\begin{tabular}{|c|c|c|c|c|c|c|}
\hline \multirow{2}{*}{ Geographical region } & \multicolumn{5}{|c|}{ Concentration of heavy metals in sediements $(\mathrm{mg} / \mathrm{Kg})$} & \multirow{2}{*}{ Ref. } \\
\hline & $\mathrm{Pb}$ & $\mathrm{Cr}$ & $\mathrm{Cu}$ & $\mathrm{Zn}$ & $\mathrm{Cd}$ & \\
\hline Ekulu river, Nigeria & 48.4 & 46.7 & 7.6 & 57.1 & 5.6 & Present study \\
\hline River Benue, Nigeria & 26.0 & 70.0 & 71.0 & 340.0 & 0.4 & {$[36]$} \\
\hline Bangshi river, Bangladesh & 60.0 & 98.0 & 31.0 & NA & 0.61 & [37] \\
\hline Yellow river, China & 15.2 & 62.4 & 40.7 & 68.4 & 0.085 & [38] \\
\hline Lake Awassa, Ethiopia & 15.7 & 8.3 & 8.7 .0 & 93.8 & 0.21 & [39] \\
\hline Lijiang river, China & 51.5 & 56.4 & 38.1 & 142.2 & 1.72 & [40] \\
\hline Neretva river Valley, Croatia & 58.7 & 42.1 & 55.1 & 58.7 & 0.31 & [41] \\
\hline Almendares river, Cuba & 189.0 & NA & 195.0 & 85.0 & 3.5 & [42] \\
\hline Axos river, Greece & 140.0 & 180.0 & 93.0 & 271.0 & 11.0 & [43] \\
\hline Gomti river, India & 156.0 & 88.7 & 245.0 & 343.0 & 17.8 & [44] \\
\hline
\end{tabular}

TABLE-4

CONCENTRATION OF THE HEAVY METALS IN THE VARIOUS SAMPLING LOCATIONS OF THE EKULU RIVER AS SAMPLED IN OCTOBER, 2017 AND FEBRUARY, 2018. VALUES ARE PRESENTED AS MEAN

\begin{tabular}{|c|c|c|c|c|c|c|c|c|}
\hline \multirow{2}{*}{$\begin{array}{l}\text { Heavy } \\
\text { metals }\end{array}$} & \multicolumn{4}{|c|}{ Concentration values (mg/L) for October, 2017} & \multicolumn{4}{|c|}{ Concentration values (mg/L) for February, 2018} \\
\hline & Onyeama & Damija & $\begin{array}{c}\text { The Gate } \\
\text { Hotel }\end{array}$ & $\begin{array}{c}\text { River waterfall } \\
\text { average }\end{array}$ & Onyeama & Damija & $\begin{array}{c}\text { The Gate } \\
\text { Hotel }\end{array}$ & $\begin{array}{c}\text { River waterfall } \\
\text { average }\end{array}$ \\
\hline $\mathrm{Pb}$ & 0.28 & 1.6 & 0.92 & 0.93 & 0.21 & 0.14 & 0.48 & 0.28 \\
\hline $\mathrm{Cu}$ & 0.005 & BDL & 0.02 & 0.008 & 0.15 & 0.014 & 0.005 & 0.056 \\
\hline $\mathrm{Cr}$ & 0.02 & 0.11 & 0.38 & 0.17 & 0.01 & BDL & BDL & 0.0033 \\
\hline $\mathrm{Zn}$ & 0.15 & 0.13 & 0.22 & 0.166 & 0.02 & 0.033 & 0.006 & 0.02 \\
\hline $\mathrm{Cd}$ & BDL & BDL & 0.01 & 0.0033 & 0.008 & 0.017 & 0.005 & 0.01 \\
\hline
\end{tabular}

$\mathrm{BDL}=$ Below detection limit 


\begin{tabular}{|c|c|c|c|c|c|c|}
\hline \multicolumn{7}{|c|}{$\begin{array}{l}\text { TABLE-5 } \\
\text { CONCENTRATION OF THE HEAVY METALS IN WATER COLUMN OF EKULU RIVER (WATER COLUMN AVERAGE } \\
\text { FOR WET AND DRY SEASONS) AS COMPARED WITH THE RIVERS OF OTHER REGIONS OF THE WORLD }\end{array}$} \\
\hline \multirow{2}{*}{ Geographical region } & \multicolumn{5}{|c|}{ Concentration of heavy metals in water column $(\mathrm{mg} / \mathrm{L})$} & \multirow{2}{*}{ Ref. } \\
\hline & $\mathrm{Pb}$ & $\mathrm{Cr}$ & $\mathrm{Cu}$ & $\mathrm{Zn}$ & $\mathrm{Cd}$ & \\
\hline Ekulu river, Nigeria & 0.403 & 0.058 & 0.021 & 0.062 & 0.0044 & Present study \\
\hline River Argungu Nigeria & 0.8 & 0.03 & 1.8 & 0.33 & 0.04 & [45] \\
\hline Houjing river Taiwan & 0.025 & 0.0025 & 0.036 & 0.032 & 0.012 & [19] \\
\hline Pardo river Brazil & 0.0005 & 0.001 & 0.0017 & 0.0013 & 0.001 & [46] \\
\hline Tembi river, Iran & 1.8 & 0.25 & 0.4 & 0.2 & 0.1 & [47] \\
\hline River Godavari, India & 0.0411 & 0.01 & 0.043 & 0.094 & 0.001 & [48] \\
\hline Mala Welna river, Poland & 0.04 & 0.009 & 0.089 & 0.115 & 0.003 & [49] \\
\hline Odiel river, Spain & 1.98 & 0.18 & 122 & 466 & 0.589 & {$[50]$} \\
\hline
\end{tabular}

the ecological risk index employed is potential ecological risk index (PERI).

The contamination factor and degree of contamination, geochemical accumulation index, pollution load index and potential ecological risk index of the heavy metals in the sediment of Ekulu river are as presented in Table-6.

From the scheme proposed by Hakanson [17], CF $<1$ implies low contamination; $\mathrm{CF}>1$ but $<3$ implies moderate contamination; $\mathrm{CF}>3$ but $<6$ implies considerable contamination; $\mathrm{CF}>6$ implies very high contamination. The contamination factor $(\mathrm{CF})$ of the heavy metals in the sediments of Ekulu river at Onyeama indicates that $\mathrm{Pb}$ and $\mathrm{Cr}$ contamination is moderate but low in The Gate Hotel and Damija. The CF of $\mathrm{Zn}$ and $\mathrm{Cu}$ for all locations indicate low contamination whereas there is moderate $\mathrm{Cd}$ contamination at Onyeama and The Gate Hotel during the rainy season but very high contamination at Damija area. During the dry season, Cd contamination of Ekulu river sediments is moderate at The Hotel, considerable at Onyeama but very high at Damija.

For all seasons, the degree of contamination (CD) of Ekulu river sediments at Waterfall and The Gate Hotel is $<7.0$ indicating low degree of contamination whereas for Damija at all seasons with $\mathrm{CD}>7$ but $<14$ indicates moderate degree of contamination [52].

The geochemical accumulation index $\left(\mathrm{I}_{\mathrm{geo}}\right)$ classification scheme proposed by Muller [53] and applied by other researchers such as Sharifi et al. [54] was used in interpreting the $\mathrm{I}_{\text {geo }}$ data. The $\mathrm{I}_{\text {geo }}$ for $\mathrm{Pb}, \mathrm{Cr}, \mathrm{Cu}$ and $\mathrm{Zn}$ in the sediments of
The Hotel for all seasons are less than 0 indicating that the sediment is not contaminated with these heavy metals but the $\mathrm{I}_{\text {geo }}$ for cadmium in both wet and dry seasons is $>0$ but $<1$ indicating moderate contamination. At Onyeama during the wet season, the $\mathrm{I}_{\text {geo }}$ for $\mathrm{Pb}$ indicates moderate contamination but no contamination for $\mathrm{Cu}, \mathrm{Cr}$ and $\mathrm{Zn}$ in both seasons. $\mathrm{Cd}$ contamination at Onyeamal for all seasons is moderate to heavily contaminated. At Damija, there is no contamination from $\mathrm{Cu}, \mathrm{Pb}, \mathrm{Cr}$ and $\mathrm{Zn}$ for all seasons but contamination from $\mathrm{Cd}$ for all seasons is heavy. The application of $\mathrm{I}_{\text {geo }}$ is based on its ability to indicate potential anthropogenic input to aquatic environment. As can be observed in Damija, where for all seasons, Cd occurred at a level of heavily contaminated, this would indicate that cadmium is released into Ekulu river around Damija area from anthropogenic sources.

Pollution load index (PLI) data in this study was interpreted according to the scheme reported by Tomlinson et al. [28] and applied by Vu et al. [19] as follows:

PLI = O: not polluted; PLI < 1: unpolluted; PLI $\geq 1$ : polluted. As PLI increases above unity, the higher the pollution. It therefore follows that the sediments at Damija area during the wet season and the sediments at Onyeama and The Hotel areas for all seasons are unpolluted as PLI values are $<1$. However, during the dry season, the sediments at Damija area is polluted as PLI $=1$.

The potential ecological risk index (PERI) in this study was interpreted using the scheme reported by Hakanson [17] as follows:

TABLE-6

SEDIMENT POLLUTION AND ECOLOGICAL RISK INDICES

\begin{tabular}{|c|c|c|c|c|c|c|c|c|c|c|c|c|c|c|c|}
\hline \multirow{2}{*}{$\begin{array}{l}\text { Heavy } \\
\text { metals }\end{array}$} & \multicolumn{5}{|c|}{ Onyeama } & \multicolumn{5}{|c|}{ Damija } & \multicolumn{5}{|c|}{ The Gate Hotel } \\
\hline & $\mathrm{CF}$ & $\mathrm{CD}$ & $\mathrm{I}_{\mathrm{geo}}$ & PLI & PERI & $\mathrm{CF}$ & $\mathrm{CD}$ & $\mathrm{I}_{\mathrm{geo}}$ & PLI & PERI & $\mathrm{CF}$ & $\mathrm{CD}$ & $\mathrm{I}_{\mathrm{geo}}$ & PLI & PERI \\
\hline & \multicolumn{15}{|c|}{ Wet season values } \\
\hline $\mathrm{Pb}$ & 1.7 & 6.4 & 0.2 & 0.1 & 102 & 0.0003 & 12.8 & -12 & 0.06 & 368 & 0.48 & 3.8 & -1.6 & 0.48 & 70.4 \\
\hline $\mathrm{Cu}$ & 0.13 & & -3.5 & & & 0.154 & & -3.3 & & & 0.092 & & -4.0 & & \\
\hline $\mathrm{Cr}$ & 1.4 & & -0.1 & & & 0.48 & & -1.6 & & & 0.5 & & -1.6 & & \\
\hline $\mathrm{Zn}$ & 0.1 & & -3.9 & & & 0.003 & & -8.8 & & & 0.497 & & -1.6 & & \\
\hline \multirow[t]{2}{*}{$\mathrm{Cd}$} & 3 & & 1 & & & 12.2 & & 3 & & & 2.2 & & 0.6 & & \\
\hline & \multicolumn{15}{|c|}{ Dry season values } \\
\hline $\mathrm{Pb}$ & 0.8 & 6 & -1 & 0.5 & 141 & 0.65 & 11 & -1.2 & 1 & 266 & 0.52 & 5.4 & -1.5 & 0.82 & 91 \\
\hline $\mathrm{Cu}$ & 0.2 & & -3 & & & 0.47 & & -1.7 & & & 0.33 & & -2.2 & & \\
\hline $\mathrm{Cr}$ & 0.45 & & -1.7 & & & 0.83 & & -0.8 & & & 0.98 & & -0.6 & & \\
\hline $\mathrm{Zn}$ & 0.11 & & -3.8 & & & 0.44 & & -1.8 & & & 0.81 & & -0.9 & & \\
\hline $\mathrm{Cd}$ & 4.5 & & 1.6 & & & 8.6 & & 2.5 & & & 2.8 & & 0.9 & & \\
\hline
\end{tabular}

$\mathrm{CF}=$ Contamination factor; $\mathrm{CD}=$ Degree of contamination; $\mathrm{I}_{\mathrm{geo}}=$ Geochemical accumulation index; $\mathrm{PLI}=$ pollution load index; PERI = potential ecological risk index. 
PERI < 110: low risk; $110 \leq$ PERI < 200: moderate risk; $200 \leq$ PERI < 400: considerable risk and $400 \leq$ PERI: very high risk. PERI values for the sediments at the Gate Hotel during all seasons are $<110$ indicating low ecological risk whereas at the Onyeama, the PERI indicates moderate risk during dry season and low risk during wet season. At Damija, the ecological risk is considerable for all seasons as PERI is $>$ 200 but $<400$.

Non-carcinogenic risk of exposure to heavy metals in water and sediments: Assessment of non-carcinogenic exposure to heavy metals using hazard index (HI) is presented in Table-7. The risk of non-carcinogenic health associated with human exposure to heavy metals via ingestion of the water and dermal contact employing hazard index (HI) indicates that the non-carcinogenic health risk is low for Onyeamal area for both seasons $(\mathrm{HI}<1)$. At Damija, there is significant noncarcinogenic risk during the wet season but low risk during the dry season (Table-7). At The Hotel, the non-carcinogenic health risks are significant at all seasons (HI $>1$ ) (Table-7). Given that the non-carcinogenic risk of exposure is significant for both seasons at The Gate Hotel and only for wet season at Damija, use of Ekulu river water for drinking and bathing should be discontinued around these locations.

\begin{tabular}{lcc|cc}
\multicolumn{5}{c}{ TABLE-7 } \\
\multicolumn{5}{c}{ NON-CARCINOGENIC RISK } \\
EXPOSURE USING HAZARD INDEX \\
\hline \multirow{2}{*}{ Location } & \multicolumn{2}{c}{ Water column } & \multicolumn{2}{c}{ Sediments } \\
\cline { 2 - 5 } & $\begin{array}{c}\text { Hazard } \\
\text { index-wet } \\
\text { season }\end{array}$ & $\begin{array}{c}\text { Hazard } \\
\text { index-dry } \\
\text { season }\end{array}$ & $\begin{array}{c}\text { Hazard } \\
\text { index-wet } \\
\text { season }\end{array}$ & $\begin{array}{c}\text { Hazard } \\
\text { index-dry } \\
\text { season }\end{array}$ \\
\hline Onyeama & 0.9 & 0.9 & 0.013 & 0.007 \\
Damija & 5.3 & 0.9 & 0.014 & 0.013 \\
The Gate Hotel & 4.7 & 1.6 & 0.006 & 0.009 \\
\hline
\end{tabular}

The human exposure to heavy metals via inadvertent ingestion of the sediment and dermal contact is very low for all locations and all seasons as the $\mathrm{HI}<1$ in all cases. This implies that the non-carcinogenic risks associated with dermal contact and ingestion of the sediment is insignificant.

Carcinogenic risk of exposure to heavy metals in water: The carcinogenic exposure risks of humans to the studied heavy metals of Ekulu river via oral ingestion of the water was estimated using excess life cancer risks (ELCR) for the individual heavy metals and risk index (RI) as the cumulative interactive effects of the individual heavy metals. The carcinogenic health effect of cadmium, lead and chromium is characterized hence their cancer slope factors expressed in $(\mathrm{mg} / \mathrm{kg}$ day $)^{-1}$ are available as $(\mathrm{Cd}=15 ; \mathrm{Pb}=0.42 ; \mathrm{Cr}=0.0085)$ [55].

The acceptable risk range for exposure to carcinogens is $1 \times 10^{-6}$ to $1 \times 10^{-4}$. At this range, risk to human health is not significant and therefore tolerable [56]. The risk index values exceed this range (Table-8) indicating that the people using this water are at a risk of carcinogenic health effects of the heavy metals in their life time. The risks are higher during the dry season for the areas within Onyeama and Damija. During the wet season, risk is highest around The Gate Hotel whereas it is highest around Damija during the dry season. The carcinogenic risk at The Gate Hotel in the wet season is about fourfold that at Damija (Table-8) indicating season related anthro-

\begin{tabular}{ccc}
\multicolumn{3}{c}{ TABLE-8 } \\
\multicolumn{3}{c}{ EXPOSURE TO CARCINOGENIC } \\
RISKS USING RISK INDEX (RI) \\
\hline \multirow{2}{*}{ Location } & \multicolumn{2}{c}{ Water column } \\
\cline { 2 - 3 } & RI $\left(10^{4}\right)$-wet season & RI $\left(10^{4}\right)$-dry season \\
\hline Onyeama & 1.03 & 12 \\
Damija & 7.00 & 25 \\
The Gate Hotel & 30.4 & 7.5 \\
\hline
\end{tabular}

pogenic heavy metal input after Damija area but before The Gate Hotel area which is most likely agricultural. Conversely, during the dry season, the carcinogenic risk at Damija is threefold that at The Hotel indicating anthropogenic input that is most likely non-agrcultural.

\section{Conclusion}

This study was conducted to ascertain the potential contamination of Ekulu river by heavy metals such as $\mathrm{Pb}, \mathrm{Cr}, \mathrm{Cu}$, $\mathrm{Zn}$ and $\mathrm{Cd}$ along about $5 \mathrm{~km}$ stretch of the river beginning from the defunct Onyeama coal mine area. Hence, the study assessed the heavy metal contamination of the river water column and sediment in addition to the ecological and human health risk exposure to these metals. The results obtained indicate that the contamination of the river water column and sediment was mainly due to $\mathrm{Cd}, \mathrm{Cr}$ and $\mathrm{Pb}$ with cadmium as the most common contaminant. The contamination of the sediments by $\mathrm{Pb}$ and $\mathrm{Cr}$ was most profound around Onyeama area during the rainy season due to the discharge of acid mine drainage into the river. The Ekulu river sediments around Damija area are the most contaminated with the heavy metals as they pose considerable risk to the biota inhabiting the sediments. There is the likelihood of anthropogenic activities such as indiscriminate waste discharge and agricultural runoff being responsible for the increased levels of $\mathrm{Cd}$ input into Ekulu river within Damija area as Cd levels in the sediments of Ekulu river within this area is relatively high. Non-carcinogenic risk of exposure to heavy metals is significant during the wet season at Damija and significant for all seasons around The Hotel but insignificant/low around the Onyeama area for all seasons. The carcinogenic risks of exposure to heavy metals are significant for all the locations at all seasons indicating that the water of Ekulu river is unfit for drinking, washing or bathing.

\section{ACKNOWLEDGEMENTS}

The authors express their appreciation for all the assistance received from the SHELL Centre for Environmental Management $\&$ Control in the course of this study.

\section{CONFLICT OF INTEREST}

The authors declare that there is no conflict of interests regarding the publication of this article.

\section{REFERENCES}

1. H. Zhu, Y. Xu, B. Yan, J. Guan, Q. Zhou and Y. Liang, Hum. Ecol. Risk Assess., (2015); https://doi.org/10.1080/10807039.2015.1104626

2. H. Singh, R. Pandey, S.K. Singh and D.N. Shukla, Appl. Water Sci., 7, 4133 (2017); https://doi.org/10.1007/s13201-017-0572-y. 
3. N.B. Dirbaba, X. Yan, H. Wu, L.L. Colebrooke and J. Wang, Water, 10, 535 (2018); https://doi.org/10.3390/w10050535.

4. C.M. Mico, L. Recatala, M. Peris and J. Sanchez, Chemosphere, 65, 863 (2006);

https://doi.org/10.1016/j.chemosphere.2006.03.016.

5. S.K. Gautam, D. Sharma, J.K. Tripathi, S. Ahirwar and S.K. Singh, Appl. Water Sci., 3, 57 (2013); https://doi.org/10.1007/s13201-012-0059-9.

6. A. Amin, S. Fazal, A. Mujtaba and S.K. Singh, J. Indian Soc. Remote Sensing, 42, 119 (2014); https://doi.org/10.1007/s12524-013-0297-9.

7. J.J. Sheng, X.P. Wang, P. Gong, L.D. Tian and T.D. Yao, Environ. Sci. Pollut. Res. Int., 19, 3362 (2012);

https://doi.org/10.1007/s11356-012-0857-5.

8. E.A. Omayma, E. Mona and F.A. Nazik, Int. J. Pharm. Sci. Rev. Res., 36, 209 (2016)

9. X. Yan, M. Liu, J. Zhong, J. Guo and W. Wu, Sustainability, 10, 338 (2018); https://doi.org/10.3390/su10020338

10. Y. Yi, Z. Yang and S. Zhang, Environ. Pollut., 159, 2575 (2011); https://doi.org/10.1016/j.envpol.2011.06.011.

11. A. Agarwal, R.D. Singh, S.K. Mishra and P.K. Bhunya, Water SA, 31, 95 (2005); https://doi.org/10.4314/wsa.v31i1.5125.

12. B.K. Hope, Environ. Int., 32, 983 (2006); https://doi.org/10.1016/j.envint.2006.06.005.

13. J. Wu, X.X. Men and K. Li, Soils, 37, 258 (2005).

14. M. Varol and B. Sen, Catena, 92, 1 (2012); https://doi.org/10.1016/j.catena.2011.11.011

15. F. Rastmanesh, S. Safaie, A.R. Zarasvandi and M. Edraki, Environ. Monit. Assess., 190, 273 (2018); https://doi.org/10.1007/s10661-018-6650-2.

16. A.P. Mucha, T.S.D. Vasconcelos and A.A. Bordalo, Environ. Pollut., 121, 169 (2003); https://doi.org/10.1016/S0269-7491(02)00229-4.

17. L. Hakanson, Water Res., 14, 975 (1980); https://doi.org/10.1016/0043-1354(80)90143-8.

18. J. Zhang, Q. Yan, J. Jiang, B. Song and T. Chen, Human Ecol. Risk Assess.: Int. J., 24, 347 (2018); https://doi.org/10.1080/10807039.2017.1383850.

19. C.T. Vu, C. Lin, K.A. Nguyen, C. Shern and Y. Kuo, Environ. Earth Sci., 77, 388 (2018) https://doi.org/10.1007/s12665-018-7573-5.

20. B.A. Alghamdi, I.E. Mannoubi and S.A. Zabin, Hum. Ecol. Risk Assess. :Int. J., (2019); https://doi.org/10.1080/10807039.2018.1451746.

21. H.I. Ezeigbo and B.N. Ezeanyim, Mine Water Environ., 12, 53 (1993).

22. E.O. Adaikpoh, G.E. Nwajei and J.E. Ogala, J. Appl. Sci. Environ. Manage., 9, 5 (2005).

23. D.C. Ozoko, J. Environ. Earth Sci., 5, 120 (2015).

24. O.O. Osinowo, J. Afr. Earth Sci., 121, 247 (2016); https://doi.org/10.1016/j.jafrearsci.2016.06.009.

25. R.A. Reyment, Aspect of Geology of Nigeria. Ibadan University Press: Ibadan, Nigeria, pp: 126 (1965)

26. U.S. EPA, Exposure Factors Handbook, Office of Research and Development, National Centre For Environmental Assessment (2011).

27. H. Pekey, D. Karakas and M. Bakoglu, Mar. Pollut. Bull., 49, 809 (2004); https://doi.org/10.1016/j.marpolbul.2004.06.029.

28. D.L. Tomlinson, J.G. Wilson, C.R. Harris and D.W. Jeffrey, Helgol. Meeresunters., 33, 566 (1980); https://doi.org/10.1007/BF02414780.

29. U.C. Ugochukwu and A. Ochonogor, Environ. Monit. Assess., 190, 249 (2018); https://doi.org/10.1007/s10661-018-6626-2.

30. M.Z.H. Naveeduallah, M.Z. Hasmi, C. Yu, H. Shen, D. Duan, C. Shen, L. Lou and Y. Chen, Pol. J. Environ. Stud., 23, 801 (2014).

31. U.S. EPA (United States Environmental Protection Agency), Groundwater Contamination. A Guide for Small Communities EPA/625/R-93/002 (1993).

32. U.S. EPA (United States Environmental Protection Agency), Guideline for Carcinogen Risk Assessment. Risk assessment forum, USEPA Washington D.C. EPA 630/P-03/001B (2005).
33. B. Wu, Y. Zhang, X.X. Zhang and S.P. Cheng, Bull. Environ. Contam. Toxicol., 84, 46 (2010); https://doi.org/10.1007/s00128-009-9900-8.

34. U.C. Ugochukwu, A. Ochonogor, C.M. Jidere, C. Agu, F. Nkoloagu, J. Ewoh and V.U. Okwu-Delunzu, Environ. Int., 115, 38 (2018); https://doi.org/10.1016/i.envint.2018.03.010.

35. Health Canada, Federal Contaminated Site Risk Assessment in Canada, Part V: Guidance on Human Health Detailed Quantitative Risk Assessment for Chemicals (2010).

36. C.I. Adamu and T.N. Nganje, Eng. Technol., 9, 1 (2009).

37. M.S. Rahman, N. Saha and A.H. Molla, Environ. Earth Sci., 71, 2293 (2014); https://doi.org/10.1007/s12665-013-2631-5.

38. N. Yan, W. Liu, H. Xie, L. Gao, Y. Han, M. Wang and H. Li, J. Environ. Sci. (China), 39, 45 (2016); https://doi.org/10.1016/j.jes.2015.10.017.

39. Y.B. Yohannes, Y. Ikenaka, A. Saengtienchai, K.P. Watanabe, S.M.M. Nakayama and M. Ishizuka, Environ. Sci. Pollut. Res. Int., 20, 8663 (2013); https://doi.org/10.1007/s11356-013-1821-8.

40. D. Xu, Y. Wang, R. Zhang, J. Guo, W. Zhang and K. Yu, Environ. Sci. Pollut. Res. Int., 23, 9122 (2016); https://doi.org/10.1007/s11356-016-6147-x.

41. D. Romic, M. Romic, M. Zovko, H. Bakic and G. Ondrasek, Environ. Geochem. Health, 34, 399 (2012); https://doi.org/10.1007/s10653-012-9449-z.

42. S. Olivares-Rieumont, D. De la Rosa, L. Lima, D.W. Graham, J. Borroto, F. Martinez and J. Sanchez, Water Resour, 39, 3945 (2005); https://doi.org/10.1016/j.watres.2005.07.011.

43. A.P. Karageorgis, N.P. Nikolaidis, H. Karamanos and N. Skoulikidis, Cont. Shelf Res., 23, 1929 (2003); https://doi.org/10.1016/j.csr.2003.06.009.

44. K.P. Singh, A. Malik, S. Sinha, V.K. Singh and R.C. Murthy, Water Air Soil Pollut., 166, 321 (2005); https://doi.org/10.1007/s11270-005-5268-5.

45. I.O. Obaroh, U. Abubakar, M.A. Haruna and M.C. Elinge, J. Fish. Aquat. Sci., 10, 581 (2015); https://doi.org/10.3923/jfas.2015.581.586.

46. C.S. Machado, B.M. Fregomesi, R.I.S. Alves, K.A.A. Tomani, J. Sierra, B.S. Martins, B.S. Celere, M. Mari, M. Schuhmacher, M. Nadal, J.I. Domingo and S. Segura-Munoz, Environ. Sci. Pollut. Res. Int., 24, 20160 (2017); https://doi.org/10.1007/S11356-017-9461-z.

47. S. Shanbehzadeh, M.V. Dastjerdi, A. Hassanzadeh and T. Kiyanizadeh, J. Environ. Public Health, 2014, Article ID 858720 (2014); https://doi.org/10.1155/2014/858720.

48. J. Hussain, I. Husain, M. Arif and N. Gupta, Appl. Water Sci., 7, 4539 (2017); https://doi.org/10.1007/s13201-017-0607-4.

49. M. Frankowski, M. Sojka, A. Ziola-Frankowska, M. Siepak and S. Murat-Blazejewska, Oceanol. Hydrobiol. Stud., 38, 51 (2009); https://doi.org/10.2478/v10009-009-0021-9.

50. S. Aguasanta, N.J. Miguel, O. Manuel and C. Carlos, Environmental Impact of Mining Activities in the Odiel River Basin (SW Spain). $9^{\text {th }}$ International Mine Water Congress, Spain (2005).

51. Canadian Council of Ministers of Environment (CCME), Canadian Sediment Quality Guidelines for the Protection of Aquatic Life, CCMEEPC-98E (1999).

52. F. Pedersen, E. Bjornestad, H.V. Andersen, J. Kjolholt and C. Poll, Water Sci. Technol., 37, 233 (1998); https://doi.org/10.1016/S0273-1223(98)00203-0.

53. G. Muller, GeoJournal, 2, 108 (1969).

54. Z. Sharifi, S.M.T. Hossaini and G. Renella, J. Geochem. Explor., 169, 202 (2016); https://doi.org/10.1016/i.gexplo.2016.08.001

55. Integrated Risk Information System (IRIS) (2018); Available at: https://cfpub.epa.gov/ncea/iris2/atoz.cfm.

56. S. Wu, S. Peng, X. Zhang, D. Wu, W. Luo, T. Zhang, S. Zhou, G. Yang, H. Wan and L. Wu, J. Geochem. Explor., 48, 71 (2015); https://doi.org/10.1016/j.gexplo.2014.08.009. 